\title{
Feeding and morphological analysis of the digestive tract of four species of fish (Astyanax altiparanae, Parauchenipterus galeatus, Serrasalmus marginatus and Hoplias aff. malabaricus) from the upper Paraná River floodplain, Brazil
}

\author{
Peretti, D. * and Andrian, IF. \\ Departamento de Ciências Biológicas, Programa de Pós-Graduação em Ecologia de Ambientes Aquáticos Continentais, \\ Universidade Estadual de Maringá - UEM, \\ Av. Colombo, 5790, Campus Universitário, Bloco G90, CEP 87020-900, Maringá, Paraná, Brazil \\ *e-mail: perettidani@gmail.com \\ Departamento de Ciências Biológicas, Universidade do Estado do Rio Grande do Norte - UERN, \\ Campus Universitário Central, Setor II, \\ Av. Antônio Campos, s/n, Bairro Costa e Silva, CEP 59610-090, Mossoró, RN, Brazil \\ Received January 30, 2007 - Accepted June 28, 2007 - Distributed August 31, 2008
}

(With 3 figures)

\begin{abstract}
The present study is inspired by the great wealth of species exhibited by the ichthiofauna. Not only concepts and techniques of ecology deserve attention, but also knowledge in other biological areas, such as zoology and anatomy, are necessary. The intention of the present work is to discover the morphology of fish through the study of the digestive tract morphology, associating it to diet data, in order to better understand the biology of four fish species of the upper Paraná River floodplain. The samples were collected quarterly in the year 2000 with gillnets of different meshes. The stomach content was analyzed under a stereoscopic microscope and the frequencies of occurrence (FO) and volumetric (FV) and the alimentary index (IAi) were calculated. Various morphologic characteristics were analyzed and schematized using a light chamber. The species were grouped into two trophic guilds - insectivores (Astyanax altiparanae and Parauchenipterus galeatus) and piscivores (Serrasalmus marginatus and Hoplias aff. malabaricus). The first two, although consumers of insects, preyed on different alimentary groups, notably Hymenoptera in the case of A. altiparanae and Coleoptera in the case of $P$. galeatus. Serrasalmus marginatus and H. aff. malabaricus consumed mainly fishes. However, only pieces of prey were usually found in the stomach content of the first species, whereas whole fishes were found in the stomach content of the second. Astyanax altiparanae exhibited characteristics that allowed it to obtain food in several compartments of the water column. Similarly P. galeatus consumed food resources that were available in all aquatic compartments, although the abilities to capture, to manipulate and to absorb food differed, as shown by the importance of teeth plates and pharyngeal teeth. Serrasalmus marginatus and $H$. aff. malabaricus, although resembling each other in many aspects of the digestive tract morphology, differed in the strategies used to capture prey. The analysis showed that, according to the main food item of the diet, the species were grouped into two trophic guilds. However, those within the same category used different feeding methods, and similarity in items consumed does not imply the same group of morphological characteristics.
\end{abstract}

Keywords: fishes, tropical region, alimentary spectrum, morphology.

\section{Alimentação e análise morfológica do trato digestório de quatro espécies de peixes (Astyanax altiparanae, Parauchenipterus galeatus, Serrasalmus marginatus e Hoplias aff. malabaricus) da planície de inundação do alto rio Paraná, Brasil}

\section{Resumo}

A grande riqueza de espécies exibida pela ictiofauna estimula a investigação e não apenas conceitos e técnicas de ecologia merecem atenção, mas também o conhecimento em outras áreas da biologia, como zoologia e anatomia, se fazem necessárias. A intenção do presente trabalho foi conhecer a morfologia de peixes através do estudo da morfologia do trato digestório, associá-lo aos dados de dieta, contribuindo para conhecer a biologia de quatro espécies de peixes da planície de inundação do alto rio Paraná. As amostras foram obtidas trimestralmente no ano 2000 com redes de espera de diferentes malhas. O conteúdo estomacal foi investigado sob microscópio estereoscópico, e as frequiências de ocorrência (FO) e volumétrica (FV) e o índice alimentar (IAi) calculados. Foram avaliadas diversas caracte- 
rísticas morfológicas e esquematizadas sob câmara clara. As espécies foram agrupadas em duas categorias tróficas - insetívoros (Astyanax altiparanae e Parauchenipterus galeatus) e piscívoros (Serrasalmus marginatus e Hoplias aff. malabaricus). As duas primeiras, embora consumidoras de insetos, exploraram grupos alimentares diferentes, destacando-se Hymenoptera para A. altiparanae e Coleoptera para P. galeatus. Serrasalmus marginatus e H. aff. malabaricus consumiram peixes, entretanto apenas pedaços de presas foram mais freqüentes para a primeira e peixes inteiros para a segunda. Astyanax altiparanae exibiu características para obter o alimento em vários compartimentos da coluna d'água. Da mesma forma, $P$. galeatus aproveita os recursos disponíveis em todo o ambiente aquático, porém as características para capturar, manipular e aproveitar o alimento diferiram e para essa espécie ressalta-se a importância das placas dentígeras e dentes faríngeos. Serrasalmus marginatus e $H$. aff. malabaricus, embora se assemelhando em muitos aspectos da morfologia do trato digestório, diferiram nas estratégias de captura das presas. As análises demonstraram que, de acordo com a dieta, considerando-se o alimento principal, as espécies foram enquadradas em duas guildas tróficas e, mesmo aqueles englobados na mesma categoria, usaram estruturas diferentes para obter o alimento. A similaridade nos itens consumidos não implica em um mesmo grupo de características morfológicas.

Palavras-chave: peixes, região tropical, espectro alimentar, morfologia.

\section{Introduction}

The study of the fish trophic ecology has stimulated much interest and encompasses diverse aspects. The great wealth of species found in rivers, lakes and seas, and the diverse forms and colors exhibited by them, provokes interest in their role in nature. In such investigation, not only concepts and techniques of ecology, but also knowledge of other biological areas such as zoology and anatomy, are necessary. Wootton (1990) suggests that to know the biology of fish in relation to their food intake, some basic subjects, such as: what, when, where and how much can be consumed, deserve investigation.

In general, the attribution of trophic guilds is based only on diet leading to possible errors. In this context, Barbieri et al. (1994) affirm that isolated interpretations of the stomach content composition can result in incorrect ecological conclusions because a multiplicity of factors (ontogenetic and environmental) interferes with the diet.

In the same way, it is not recommended to make inferences regarding the alimentary habits of the species based only on morphological aspects, since the species can show morphological arrangements that indicate the exploitation of a particular food type, but an alimentary habit different from that expected may be found from diet analysis, as described by Bone et al. (1995).

In this way, the intention of the present work was to discover the morphology of fish through the study of the digestive tract morphology, associating them to the diet data, thus contributing to the understanding of the biology of four fish species of the upper Paraná River floodplain.

\section{Material and Methods}

The research was conducted in the upper Paraná River floodplain located between the coordinates $22^{\circ} 40^{\prime}-22^{\circ} 50^{\prime} \mathrm{S}$ and $53^{\circ} 15^{\prime}-53^{\circ} 40^{\prime} \mathrm{W}$ (Maack, 1981; Paiva, 1982).
To obtain the diet data, the species Astyanax altiparanae Garutti and Britski, 2000, Parauchenipterus galeatus (Linnaeus, 1766), Serrasalmus marginatus Valenciennes, 1847 and Hoplias aff. malabaricus (Bloch, 1794) were collected quarterly in the year 2000 (Table 1) with gillnets of various meshes.

Eleven individuals of $A$. altiparanae, 71 of P. galeatus, 52 of $S$. marginatus and 27 of $H$. aff. malabaricus were analyzed. The stomach contents were investigated under a stereoscopic microscope, at the smallest taxonomic level possible. The date of occurrence and volume $(\mathrm{mL})$ of the diet components were obtained. The frequencies of occurrence (FO) and volumetric frequency (FV) (Hynes, 1950; Hyslop, 1980) were calculated and hence the alimentary index (IAi) (Kawakami and Vazzoler, 1980).

$$
\mathrm{IAi} \%=\frac{\mathrm{FO} \times \mathrm{FV}}{\sum(\mathrm{FO} \times \mathrm{FV})} \times 100
$$

where: IAi = alimentary Index; FO = frequency of occurrence; $\mathrm{FV}=$ volumetric frequency.

After considering the main item that embodied the fishes in the trophic guild, the contribution of each component was verified.

For the morphological analysis, 15 individuals of A. altiparanae, 10 of $P$. galeatus, 11 of $S$. marginatus and 10 of $H$. aff. malabaricus were used. Each was weighed and measured. They were considered adults, in agreement with the first maturation length data of Nakatani et al. (2001).

The observations were made in fresh and preserved (in formaline 10\%) individuals. Aspects such as mouth position, presence and arrangement of teeth (mouth and pharynx) were verified. The analysis of the gill rakers was done in the first arch on the right side. After a ventral incision, the organs were removed and measured. The stomach shape and the presence of the pyloric cecum were verified. 
Table 1. Number of individuals collected in each sampling phase.

\begin{tabular}{lccccc}
\hline & February & May & August & November & Total \\
\hline Astyanax altiparanae & 4 & - & 2 & 5 & 11 \\
Parauchenipterus galeatus & 28 & 19 & 2 & 22 & 71 \\
Serrasalmus marginatus & 27 & 8 & 3 & 14 & 52 \\
Hoplias aff. malabaricus & 10 & 3 & 12 & 2 & 27 \\
\hline
\end{tabular}

The amount of folds in the intestine was measured. It was then unfolded and the intestinal length $(\mathrm{Li})$, which extends from the pyloric valve to rectum (in centimeters), was obtained. The intestinal quotient (QI) (Angelescu and Gneri, 1949; Barbieri et al., 1994) was calculated according to the equation:

$Q I=L i / L s$

where: $\mathrm{QI}=$ intestinal quotient; $\mathrm{Li}=$ intestine length; $\mathrm{Ls}=$ standard length.

In this text, average values are referred to, with a respective deviation pattern (d.p.).

The structures of the digestive tract were schematized under a light chamber coupled in stereomicroscopic.

To summarize the feeding data, a detrended correspondence analysis (DCA) was applied (Gauch-Jr, 1982; Graham and Vrijenhoek, 1988), based on the volume of the alimentary items, using PC-Ord version 4.01 and Statistica version 7.1 software.

\section{Results}

The A. altiparanae diet was composed not only of insects, including several families and several stages of development, but also other items such as other invertebrates, microcrustaceans, scales, algae, high plant and organic detritus. For the main contributions, the items were grouped into four categories: insects, algae - high plant, scales and other (other invertebrates, microcrustaceans and organic detritus).

The insects contributed, in values of IAi, to $65.4 \%$ of the diet, followed by algae-high plants $(23.8 \%)$, scales $(4.5 \%)$ and other items (6.3\%) (Figure 1-a1). Within the components of the insect category, Hymenoptera contributed to $64.2 \%$, followed by Ephemeroptera (19.7\%), Diptera (6.0\%), Coleoptera (5.3\%), rest of insects (3.5\%) and Hemiptera (1.3\%) (Figure 1-a2).

The diet of $P$. galeatus, compared to A. altiparanae, was quite varied, having items such as insects, mollusks, other invertebrates, fish, fungus, algae, high plant, organic detritus and detritus/sediment. The main items were verified by grouping the diet in four categories: insects, other items (mollusks, other invertebrates, fungus, organic detritus and detritus/sediment), fish and algae - high plant, having alimentary index values (IAi) of $52.3 \%, 35.9 \%$, $7.3 \%$ and $4.6 \%$, respectively (Figure 1-b1).

Among the insects, the great variety of orders and families in several development stages is emphasized. The insects, which contributed to more than half of the diet, were represented mainly by Coleoptera $(39.3 \%)$,
Ephemeroptera (37.0\%), Hymenoptera (16.8\%), Hemiptera (2.8\%), Odonata $(2.2 \%)$ and other insects (Blattodea, Diptera, Homoptera, Isoptera, Lepidoptera, Orthoptera, Trichoptera, still including eggs and the rest of insects) (2.0\%) (Figure 1-b2).

The alimentary spectrum of $S$. marginatus was composed of fish, insects, other invertebrates, mollusks, algae, high plant and organic detritus. The items, grouped in four categories, were fish, representing $94.4 \%$ of the diet, followed by algae - high plant $(2.5 \%)$, other (other invertebrates, mollusk and organic detritus) (1.6\%) and insects (1.6\%) (Figure 1-c1). The main item, fish, is the result composed of a collection of leftovers, such as pieces of fins and muscle (97.8\%), Moenkhausia intermedia (Eigenmann,1908) (1.5\%) and other elements (scales, Roeboides paranensis (Pignalberi, 1975) and Siluriformes) (0.7\%) (Figure 1-c2).

Hoplias aff. malabaricus fed on insects, other invertebrates, represented by the shrimp Macrobrachium amazonicum (Heller, 1862), fish, algae, high plant and organic detritus.

Fish made up $81.7 \%$ of the diet, followed by shrimp $(17.8 \%)$ and other items (insects, algae, high plant and organic detritus) $(0.5 \%)$ (Figure 1-d1). Among fish, the leftovers were most important $(51.1 \%)$, followed by Steindachnerina insculpta (Fernández-Yépez, 1948) (36.7\%), Cyphocharax modestus (Fernández-Yépez, 1948) (6.4\%), H. aff. malabaricus (2.4\%), Myloplus laevis (Eigenmann and McAtee, 1907) (2.0\%) and other items (Moenkhausia intermedia, Satanoperca pappaterra (Heckel, 1840) and scales) (1.4\%) (Figure 1-d2).

The similarity between the diets, in other words, how the species are grouped based on the food type, was verified through detrended correspondence analysis (DCA) (eigenvalues for axis $1=0.88$ and axis $2=0.64$ ) (Figure 2a). The items were grouped in 10 categories insects, other invertebrates, microcrustaceans, mollusks, shrimp, fish, Basidiomicota, algae, high plant and detritus/sediment. The main contributions to the separation of the species, due to a larger correlation, were insects, shrimp and fish for axis 1 and insects, mollusks, shrimp and high plants for axis 2 .

The species ordination allowed us to observe that, among the four species, $P$. galeatus was the one that consumed the largest amount of items, i.e., practically all. The great alimentary spectrum of A. altiparanae and $S$. marginatus was still seen. As for the piscivorous, in spite of their being considered specialists due to their morphological characteristics, a diversity of items was consumed. However, a clear segregation among the spe- 

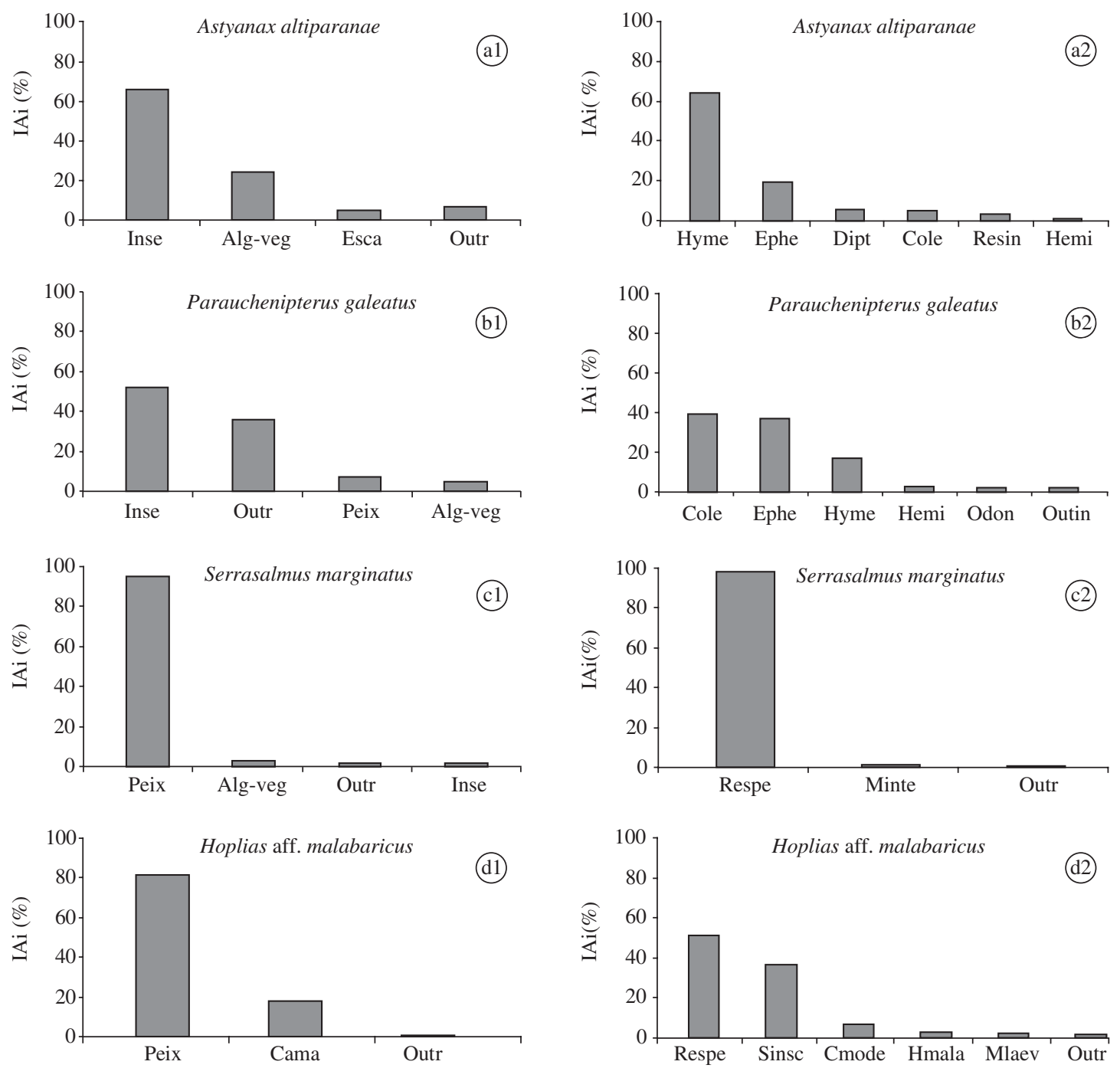

Figure 1. Diet a1, b1, c1 and d1) and main item composition a2, b2, c2 e d2) of the four studied species. inse = insects; alg-veg $=$ algae-high plant; esca $=$ scales; outr $=$ others; Hyme $=$ Hymenoptera Ephe $=$ Ephemeroptera Dipt $=$ Diptera; Cole $=$ Coleoptera; resin $=$ rest of insects; Hemi $=$ Hemiptera; peix $=$ fishes $;$ Odon $=$ Odonata $;$ outin $=$ other insects; respe $=$ rest of fishes; Minte = Moenkhausia intermedia $;$ cama $=$ shrimp; Sinsc $=$ Steindachnerina insculpta $;$ Cmode $=$ Cyphocharax modestus; Hmala = Hoplias aff. malabaricus; Mlaev = Myloplus laevis .

cies along axis 1 of illustration $2 b$ is seen, creating 2 different groups: 1) $S$. marginatus/H. aff. malabaricus and 2) P. galeatus/A. altiparanae, according to the main composition of the diets (Figure 2a).

Astyanax altiparanae has a high and flat body sidelong, with a terminal mouth that when opened, presents certain protrability (Figure 3-a1). The teeth are pentacuspidate and arranged in two rows on the maxilla (an internal and an external one) and a row on the jaw (Figure 3-a2). It does not have palatine or pharingeal teeth.

It has four gill arches, the last one being attached to the branchial cavity. The rakers are long and with little space between them (Figure 3-a3). The stomach is of saciform type with delicate walls (Figure 3-a4). In the area of the pylorum are the pyloric ceca.

The intestine has two folds. The intestinal quotient is $1.35(\mathrm{~s} . \mathrm{d}=0.37)$.

Parauchenipterus galeatus has a cylindrical and prolonged body and the head is slightly flat ventrally. The species has a terminal mouth, although lightly superior, being considered prognate. The head has a pair of barbels on the maxilla and two on the jaw (Figure 3-b1).

The maxilla and jaw possess short and sharp little teeth arranged in plates, mainly in the anterior region. Immediately behind the area of the teeth plates, there is a gathering of gustative buttons (Figure 3-b2). The buccal cavity, close to the pharingeal region, has two round 

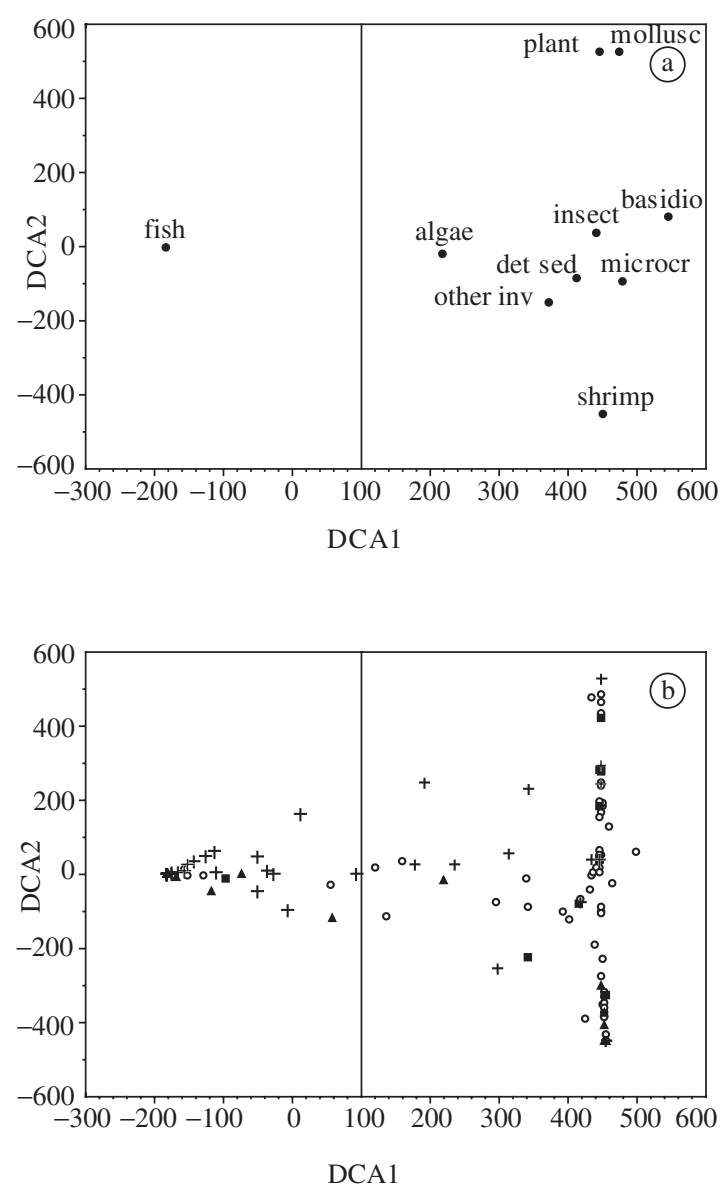

$\begin{array}{ll}+ \text { S. marginatus } & \circ \text { P. galeatus } \\ \text { \H. aff. malabaricus } & \text { A. altiparanae }\end{array}$

Figure 2. Axes 1 (DCA1) and 2 (DCA2) of DCA for items (a) basidi $=$ Basidiomicota; camara $=$ shrimp; detsed $=$ detritus $/$ sediment; microc $=$ microcrustaceans; molusc $=$ Mollusca; peixes $=$ fish; algas $=$ algae; inseto $=$ insect; outinv $=$ other invertebrates; vegeta $=$ plant material and for species $(b)$.

bony plates, like two cushions, covered by small conical teeth (pharingeal teeth).

It has five gill arches, the last minor and linked to the wall of the branchial cavity.

The gill rakers are short and round on the tip with a lot of space and covered with a mucus layer (Figure 3-b3).

The stomach is saciform, but the walls are very thick and rigid (Figure 3-b4). The pyloric ceca are absent.

The intestine, in spite of having only two folds, is quite pleated. The intestine also has rigid walls and a wide diameter compared to A. altiparanae. The intestinal coefficient indicates that length is smaller than body size $(\mathrm{QI}=0.96$; s.d. $=0.09)$.

Serrasalmus marginatus is a sidelong predator with a high and flat body. It has a superior mouth with light protrability when opened. On the nostrils there is a quite pronounced skin in the form of an arch (Figure 3-c1).

Tricuspidate teeth are set in a row, on the maxilla and on the jaw. Triangular palatine teeth are present in the buccal cavity, arranged in a row (Figure 3-c2).

This species has five gill arches, with the last one attached. The gill rakers are short, sharp and spaced, being concentrated in the curvature of that organ (Figure 3-c3). The remainder of the surface is covered by rudimentary traces.

The stomach is saciform with a thin and elastic wall (Figure 3-c4). In the pylorum area are the pyloric ceca.

The intestine has two folds and is practically equal to the body size $(\mathrm{QI}=1.07$; s.d. $=0.19)$.

Hoplias aff. malabaricus has a prolonged and cylindrical body. The head is prolongated and over almost all the surface sensorial cephalic pores are present. The mouth is wide and superior (Figure 3-d1).

The maxilla and jaw have, externally, a row of sharp irregularly-spaced conical teeth. The teeth of the anterior region of the jaw are larger than those of the posterior region and there are depressions in both parts to fit them. Still in the buccal cavity, a row of small conical teeth with the end turned back are arranged in the palatine area (Figure 3-d2).

The species has four gill arches, the last smaller and attached to the branchial cavity wall. The gill rakers are quite small, spaced and with a round tip (Figure 3-d3). The rakers are concentrated on the gill arch curvature and the remaining surface is covered by rudimentary rakers, being just small saliencies covered with small thorns.

The stomach has a "J" shape with rigid walls, although very elastic (Figure 3-d4). There are pyloric ceca in the pylorum area.

The intestine, of narrow diameter, has two folds and is smaller than the body size $(\mathrm{QI}=0.83$; s.d. $=0.09)$.

\section{Discussion}

From to the species gastric content analysis, it was seen that A. altiparanae and $P$. galeatus are carnivorous species, more precisely insectivores, due to the prevalence of insects in the diet. The species were embodied in that same trophic guild, in previous studies by Peretti and Andrian (2004). The diet of A. altiparanae was composed of items of animal and plant origin, which may lead to its classification as omnivorous, but in accordance with the statements of Andrian et al. (1994a), the species should be considered omnivorous with a tendency to insectivory due to the prevalence of insects.

Cassemiro et al. (2002) evaluated the diet of A. altiparanae in the area of the Salto Caxias reservoir, Paraná, and observed a clear tendency to herbivory, although the diet was complemented by several orders of insects and microcrustaceans. Andrian et al. (2001) identified A. bimaculatus as an opportunistic species, with omnivorous habits and a tendency toward herbivory-insetivory, in the area of the Corumbá reservoir. 

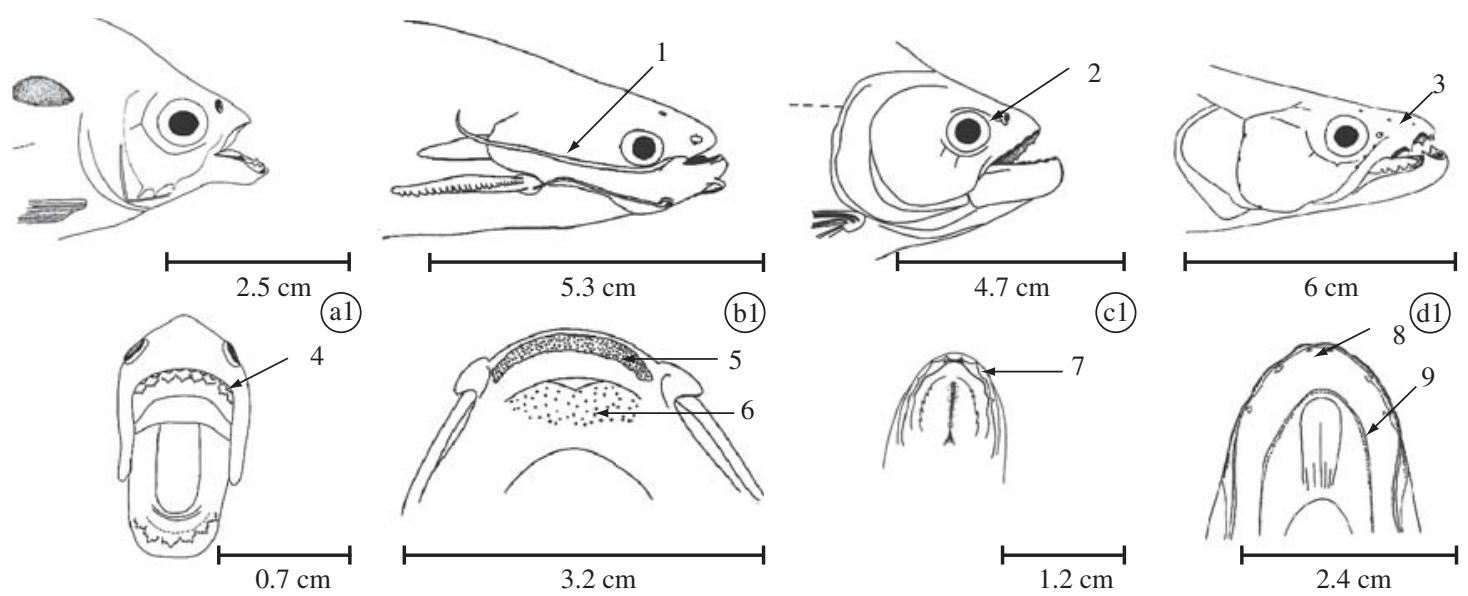

(a2)

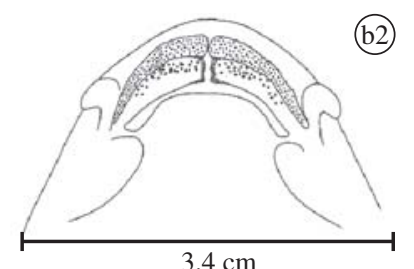

(c)

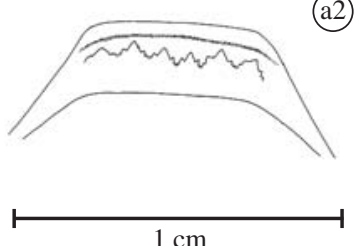

(b2)
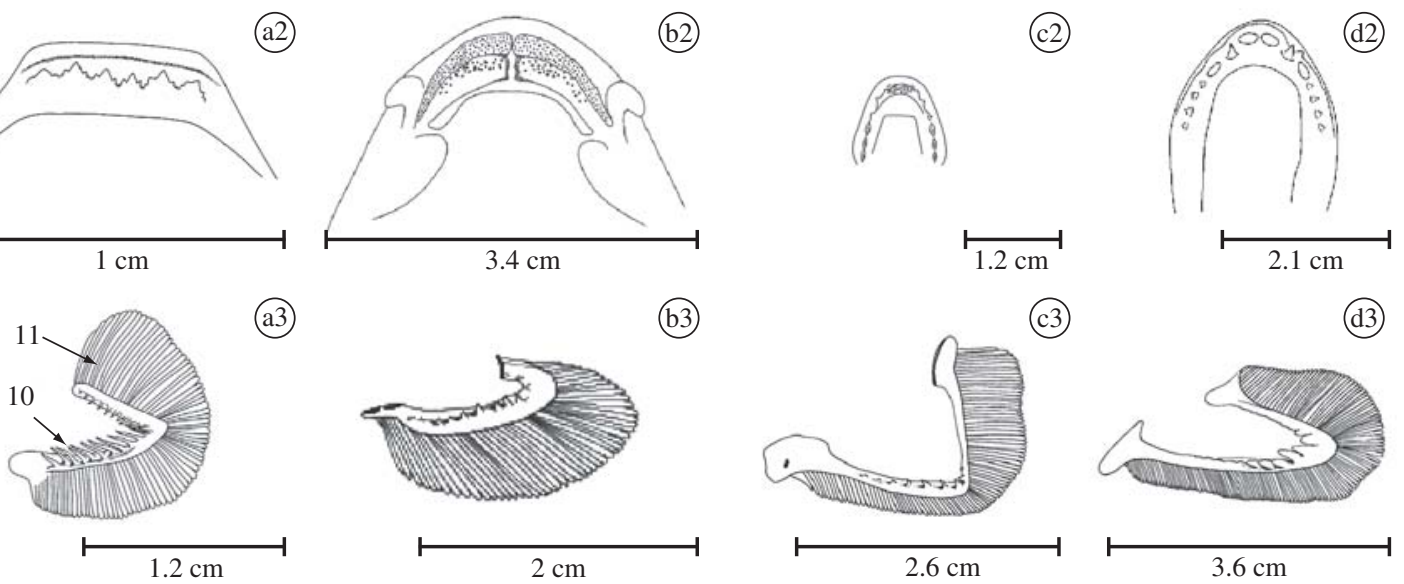

(b3)
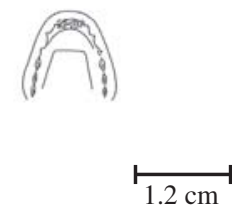

(d3)

(c)
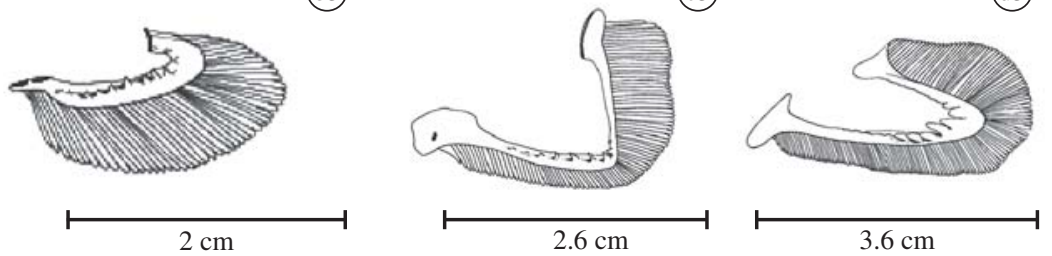

(a4)

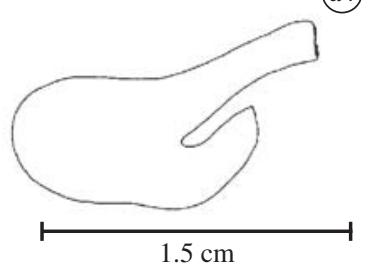

(b4)

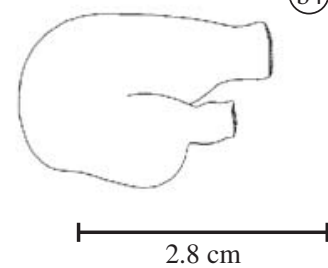

(c4)

(d4)
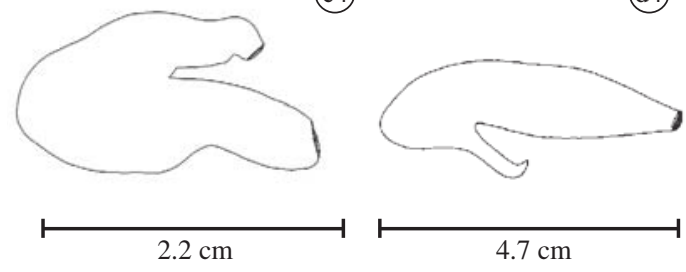

Figure 3. Scheme of the digestive tract structures of the four studied species. $1=$ barbel; $2=$ nasal membrane; $3=$ sensorial cephalic pore; $4=$ pentacuspidate teeth; $5=$ teeth plate; $6=$ gustative buttons; $7=$ tricuspidate teeth; $8=$ conical teeth; $9=$ palatine teeth; $10=$ gill rakers; $11=$ gill filaments.

Andrian and Barbieri (1996) registered, as components of the P. galeatus diet, insects, mainly Coleoptera and Hymenoptera, other invertebrates, fish remains and high plant material, demonstrating that their diet is composed of aquatic and terrestrial items. This is in agreement with the statements of Lagler et al. (1977) who consider that many fish species have flexible diets, using resources more readily available in the environment, only a few being strictly carnivorous or herbivorous.

Astyanax altiparanae and $P$. galeatus are fish that feed, in general, on items of the same origin, but they differ in relation to the predominance of insect orders (Hymenoptera and Coleoptera) consumed.

In relation to the characteristics of the digestive tract, A. altiparanae, which possesses a terminal mouth, is capable of exploring several compartments of the aquatic environment where it looks for food, in agreement with Rotta (2003). Parauchenipterus galeatus has a terminal mouth, but slightly superior, and prognata that enables it to take in food at the water surface. However the presence of barbels on the maxilla and jaw indicates that the species can also explore deeper areas of the water bodies 
and that there is not a preference for exploring a particular compartment. This is the reason why both diets contain insects that fall onto the water surface or that are at the bottom as Diptera larvae. This is in agreement with the statement made by Zavala-Camin (1996), relating to sea rays, who affirms that teeth shape is not only a consequence of the food type, but could also depend on the characteristics of the water bed. This explains the presence of teeth plates in P. galeatus and the detritus and sediment ingestion, when compared to A. altiparanae.

In rivers and small lagoons, the insects have an important role in fish diets and are usually present throughout the year, although they are more available in flood periods. The adult insects can float or sink when they fall into the water or they can be weighed down by the rain. They can also be captured by specialized fish when they land close to the water surface. Among larval forms, the aquatic ones are used more as food, but terrestrial larvae are also taken (Zavala-Camin, 1996). Andrian et al. (1994b) describe that in the middle of the communities found in the upper Paraná River floodplain, the insect community is one of the most important. The main orders are Chironomidae and Ephemeroptera, which constitute part of many diet species, including A. altiparanae and P. galeatus.

For a prey to be included in a predator diet, it needs to be localized, pursued, captured, manipulated and ingested (Mittelbach, 2002), Ingestion of the component items of the diet also depends on their palatability and the presence of gustative buttons on the surface or around the buccal cavity, which influences the choice. A concentration of them in P. galeatus was seen close to the teeth plates.

After being apprehended, the food is manipulated and processed mainly in the oro-branchial cavity. The apprehended food is swallowed whole or cut, as in the case of the plant material ingested by A. altiparanae, which is torn or has the surface scraped by pentacuspidate teeth. Astyanax bimaculatus (Linnaeus, 1758) studied by Lobón-Cerviá and Bennemann (2000) in the Tibagi river, Paraná, fed on insects, among them Ephemeroptera, Hymenoptera and Coleoptera, plant material and scales. The last two are easier to consume because of the teeth type. Parauchenipterus galeatus ingests big insects of very quitinous bodies, such as Scarabaeidae beetles, and uses teeth plates to knead the animal bodies and leave the content more exposed.

The gill rakers, although longer and fewer spaced in A. altiparanae when compared to $P$. galeatus, also contribute to item apprehension, mainly the smaller ones, which explains the presence of insect larvae in both diets. Microcrustaceans appeared in the A. altiparanae diet, corroborating the affirmation of Zavala-Camin (1996) that the smaller the space between rakers, the smaller the food particles retained. Besides, rakers are more numerous in A. altiparanae than in P. galeatus. In $P$. galeatus a mucus layer was observed covering rakers which also aids in the apprehension of benthonic items, such as aquatic insect larvae on the water bed.

The saciform stomach, in both species, is in conformity with the wide range of items ingested by them, but the walls are found to be more rigid and resistant in $P$. galeatus, which explains the presence of hard items, such as insects, mainly Coleoptera, in the stomach content.

The intestine in both is relatively short, which is typical of carnivores. The values of the intestinal quotient were measured in accordance to Weatherley and Gill (1987), and varied from 0.7 to 1.5 for carnivores and from 1.0 to 1.3 for omnivores. The differences in the intestinal quotient values between A. altiparanae and P. galeatus allow one to infer that the first species should be considered as omnivorous with an insectivory tendency. Those authors still affirm that the intestine length can be the main adaptative specialization in trophic ecology of fish. Even among the carnivorous fish, the intestine length is related to prey size, being larger in those that consume smaller animals, such as A. altiparanae. The presence of plant material in the gastric content demonstrates that the food needs more time in contact with the intestine for better nutrient absorption.

The piscivores are defined as carnivores that primarily consume fish. However, when observed in detail, piscivorous behavior is complex and flexible, dealing with different types of prey (Mittelbach, 2002). From $S$. marginatus and $H$. aff. malabaricus diets, it was possible to identify items of origin other than fish. The ingestion of insects and plant material was verified, the latter being the result of lunges of the predators on prey. Moraes and Barbola (1995), studying the feeding and the morphology of the digestive tract of $H$. malabaricus in the Lagoa Dourada, Ponta Grossa, found in the adult phase a diet based exclusively on fish and its fragments. However, a fraction of plant fragments was also found, which, according to the authors, should be understood as accidental, due to the voracious character of the species that swallows parts of the vegetation that is close by when attacking the prey.

Resende et al. (1996) identified fish as a predominant item in the diet of S. marginatus and H. malabaricus. However, in the stomach content of the first species, only fin rays and scales were found, indicating that the habit of the species is not always to ingest the whole prey but mutilate it. The rest of plants, detritus, sand and crustaceans were also verified. The diet of the second species was composed mainly of whole fish, but plant material and shrimps were also consumed. These results were corroborated by this study.

Although the two species consumed fish, the strategies to obtain food are different. While $H$. aff. malabaricus ingests mainly whole prey, $S$. marginatus cuts them into pieces, although some whole fish were also found. Janovetz (2005), in experimental studies on the piranha Catoprion mento (Cuvier, 1819), that feeds basically on scales and pieces of fins, mentions several research stud- 
ies on how the lepidofagic habit is dispersed, on morphologic diversity and attack behavior, and how nutritious and advantageous that food source is.

Besides, other structures are associated to food capture. For instance, it was observed that the nostrils of $S$. marginatus are more developed than in $H$. aff. malabaricus and that the presence of a membrane in the border of the nasal cavity can be used for the water movement inside it, making chemical stimulus more pronounced.

In $H$. aff. malabaricus, the presence of cephalic pores, dorsal and ventral, was observed. These sensorial pores probably have a function in prey detection and could feel the mechanical stimulus of the water movement before moving toward it.

The mouth of both is superior and quite wide, but a difference exists in relation to teeth type. In $S$. marginatus, the tricuspidate teeth are used to cut parts of the prey, while the canine teeth of $H$. aff. malabaricus are appropriate to catch the prey. The presence of palatine teeth with the extremities turned back, in both species, and distributed in a row, may have as functions avoiding the prey escaping from the oro-branchial cavity and avoiding tearing skin and exposing the muscle of the prey to be better digested and absorbed (Jobling, 1995). Small teeth were also verified on $H$. malabaricus tongue. As most of the fish (carnivorous) ingest whole food, the more common function of the jaw teeth is to hold food, aided by the vomer, palatine and tongue teeth (Zavala-Camin, 1996).

The gill rakers in both species are short and well spaced, and probably only serve to guarantee that the prey stays in the oro-branchial cavity. The number of rakers was small, but always accompanied by other rudimentary ones being distributed on the gill arches.

The shape of the stomach varied, being saciform for S. marginatus and a "J" shape or sifonal for $H$. aff. malabaricus (Suyehiro, 1942), being very elastic in both cases.

Jobling (1995) describes the piscivorous intestine as quite short. In general it is smaller than the total length of the fish, which is explained by the food quality and by the ease of digestion. The intestinal quotient results showed that the organ, on average, has practically the same length as the standard length of the fish ( $S$. marginatus) or is inferior to it ( $H$. aff. malabaricus). In spite of the short intestine, nutrient absorption can be increased by the presence of the pyloric cecum.

In conclusion, the analyses demonstrated that in agreement with the diet, considering the main food items, the species were embodied in two trophic guilds - insectivores (Astyanax altiparanae and Parauchenipterus galeatus) and piscivores (Serrasalmus marginatus and Hoplias aff. malabaricus). Even embodied in the same guild, the structures used to obtain food are different and the similarity in the consumed items does not imply the same group of morphologic characteristics. Each species, finally, uses a different group of characters to obtain food. This is important to avoid competition and alimentary overlap, phenomena that would reduce survival and fitness of the species.

Acknowledgements - We are grateful to Dr. Ângelo Antônio Agostinho, Dra. Vera Lúcia Lescano de Almeida, Dra Sirlei Terezinha Bennemann and Dr. Horácio Ferreira Júlio-Junior for suggestions; to Gisele Caroline Nowakowski for the main explanations of the use of the light chamber; to the project PELD/CNPq for financial support and to CAPES for the scholarship.

\section{References}

ANDRIAN, IF. and BARBIERI, G., 1996. Espectro alimentar e variações sazonal e espacial na composição da dieta de Parauchenipterus galeatus Linnaeus, 1766, (Siluriformes: Auchenipteridae) na região do reservatório de Itaipu, PR. Rev. Bras. Biol. = Braz. J. Biol., vol. 56, no. 2, p. 409-422.

ANDRIAN, IF., DÓRIA, CRC., TORRENTE, G. and FERRETTI, CM., 1994a. Espectro alimentar e similaridade na composição da dieta de quatro espécies de Leporinus (Characiformes: Anostomidae) do rio Paraná $\left(22^{\circ} 10^{\prime}-22^{\circ} 50^{\prime} \mathrm{S} /\right.$ $53^{\circ} 10^{\prime}-53^{\circ} 40^{\prime} \mathrm{W}$ ), Brasil. Rev. UNIMAR, vol. 16 no. (supl. 3), p. $97-106$

ANDRIAN, IF., LANSAC-TÔHA, FA. and ALVES, LF., 1994b. Entomofauna disponível para a alimentação de peixes, comedores de superfície, em duas lagoas da planície de inundação do alto rio Paraná, Brasil. Rev. UNIMAR, vol. 16, no. 3 , p. $117-126$.

ANDRIAN, IF., SILVA, HBR. and PERETTI, D., 2001. Dieta de Astyanax bimaculatus (Linnaeus, 1758) (Characiformes, Characidae), da área de influência do reservatório de Corumbá, Estado de Goiás, Brasil. Acta Scientiarum, vol. 23, no. 2, p. $435-440$.

ANGELESCU, V. and GNERI, FS., 1949. Adaptaciones del aparato digestivo al régimen alimentício em algunos peces Del rio Uruguay y Del rio de la Plata. I - Tipo omnivoro e iliofago em representantes de las familias Loricariidae y Anostomidae. Rev. Inst. Nac. Invest. Cienc. Nat., vol. 1, no. 6, p. 161-272.

BARBIERI, G., PERET, AC. and VERANI, JR., 1994. Notas sobre a adaptação do trato digestivo ao regime alimentar em espécies de peixes da região de São Carlos, SP. I. Quociente intestinal. Rev. Bras. Biol. = Braz. J. Biol., vol. 54, no. 1, p. 63-69.

BONE, Q., MARSHAL, NB. and BLAXTER, JHS., 1995. Biology of fishes. London: Chapman \& Hall.

CASSEMIRO, FAS., HAHN, NS. and FUGI, R., 2002. Avaliação da dieta de Astyanax altiparanae Garutti \& Britski, 2000 (Osteichthyes: Tetragonopterinae) antes e após a formação do reservatório de Salto Caxias, Estado do Paraná, Brasil. Acta Sci.Biol., vol. 24, no. 2, p. 419-425.

GAUCH JUNIOR, HG., 1982. Multivariate analysis in community ecology. Cambridge: Cambridge University Press.

GRAHAM, J. and VRIJENHOEK, RC., 1988. Detrended correspondence analysis of dietary data. Trans. Amer. Fish. Soc., vol. 117, no.1, p. 29-36.

HYNES, HBN., 1950. The food of freshwater sticklebacks (Gasterosteus aculeatus and Pygosteus pungitius) with a review methods used in studies of food of fishes. J. Anim. Ecol., vol. 19, no.1, p. 35-38. 
HYSLOP, EJ., 1980. Stomach contents analysis - a review of methods and their application. J. Fish Biol., vol. 17, no. 4, p. 411-429.

JANOVETZ, J., 2005. Functional morphology of feeding in the scale-eating specialist Catoprion mento. J. Experim. Biol., vol. 208 , p. 4757-4768.

JOBLING, M., 1995. Environmental Biology of Fishes. London: Chapman \& Hall.

KAWAKAMI, E. and VAZZOLER, G., 1980. Método gráfico e estimativa de índice alimentar aplicado no estudo de alimentação de peixes. B. Inst. Ocean., vol. 29, no. 2, p. 205-207.

LAGLER, K., BARDACH, JE., MILLER, RR. and PASSINO, DRM., 1977. Ichthyology. New York: John Wiley \& Sons.

LOBÓN-CERVIÁ, J. and BENNEMANN, ST., 2000. Temporal trophic shifts and feeding diversity in two sympatric, neotropical, omnivorous fishes: Astyanax bimaculatus e Pimelodus maculatus in rio Tibagi (Paraná, Southern Brazil). Archiv fur Hydrobiologie, vol. 148, no. 2, p. 285-306.

MAACK, R., 1981. Geografia física do estado do Paraná. Rio de Janeiro: J. Olympio.

MITTELBACH, GG., 2002. Fish foraging and habitat choice: a theoretical perspective. In Hart, PJB. and Reynolds, JD. (Ed.). Fish Biology and Fisheries. Oxford: Blackwell Publishing.

MORAES, MFPG. and BARBOLA, IF., 1995. Hábito alimentar e morfologia do tubo digestivo de Hoplias malabaricus (Osteichthyes: Erythrinidae) da Lagoa Dourada, Ponta Grossa, Paraná, Brasil. Acta Biol. Paran., vol. 24, p. 1-23.
NAKATANI, K., AGOSTINHO, AA., BAUMGARTNER, G., BIALETZKI, A., SANCHES, PV., MAKRAKIS, MC. and PAVANELLI, CS., 2001. Ovos e larvas de peixes de água doce: desenvolvimento e manual de identificação. Maringá: EDUEM.

PAIVA, MP., 1982. Grandes represas do Brasil. Brasília: Editerra.

PERETTI, D. and ANDRIAN, IF., 2004. Trophic structure of fish assemblages in five permanent lagoons of the high Paraná river floodplain, Brazil. Env. Biol. Fish., vol. 71, no.1 p. 95-103.

RESENDE, EK., PEREIRA, RAC., ALMEIDA, VLL. and SILVA, AG., 1996. Alimentação de peixes carnívoros da planície inundável do rio Miranda, Pantanal, Mato Grosso do Sul, Brasil. Corumbá: EMBRAPA-CPAP. (Boletim de Pesquisa 03).

ROTTA, MA., 2003. Aspectos gerais da fisiologia e estrutura do sistema digestivo dos peixes relacionados à piscicultura. Corumbá: Embrapa Pantanal. (Documento 53).

SUYEHIRO, Y., 1942. A study of the digestive system and feeding habits of fish. Japan. J. Zool., vol. 10, no. 1, p. 1-303.

WEATHERLEY, AH. and GILL, HS., 1987. Feeding relations, correlated functional morphology, growth and size. In Weatherley, AH. and Gill, HS. (Eds.). The biology of fish growth. London: Academic Press. p. 258-320.

WOOTOM, RJ., 1990. Ecology of teleost fishes. London: Chapman and Hall.

ZAVALA-CAMIN, LA., 1996. Introdução aos estudos sobre alimentação natural em peixes. Maringá: EDUEM. 